Jurnal Ilmu Budaya, Vol. 18, No. 1 Agustus Tahun 2021

\title{
THE ANALYSIS OF TRANSLATION TECHNIQUES IN TRANSLATING AHMAD FUADI'S NEGERI 5 MENARA INTO ANGIE KILBANE'S THE LAND OF 5 TOWERS
}

\author{
Nanda Rahmaningsih ${ }^{1}$, Sorta Hutahaean ${ }^{2}$ \\ Universitas Lancang Kuning, Pekanbaru \\ nandaraahmaningsih@yahoo.co.id, sortahutahaean01@gmail.com
}

\begin{abstract}
This research about The Analysis of Translation Techniques in Translating Ahmad Fuadi's Negeri 5 Menara into Angie Kilbane's The Land of 5 Towers. This analysis is a library research and applying descriptive method. From the analysis it found out that the translator applies all of eighteen techniques translation by Molina and Albir, they are: Pure Borrowing with 23 data. Naturalized Borrowing with 17 data. Calque with 13 data. Literal Translation with 17 data. Compensation with 4 data. Transposition with 27 data. Description with 9 data. Modulation with 69 data. Amplification with 18 data. Adaptation with 33 data. Established Equivalent with 6 data. Generalization with 17 data. Particularization with 4 data. Reduction with 22 data. Discursive Creation with 2 data. Substitution, Linguistic Compression, and Linguistic Amplification with 5 data. Variation with 7 data. The most dominant technique used is Modulation with 69 data, while the most less technique used is Discursive Creation with 2 data.
\end{abstract}

Keywords: Novel, Translation Techniques, The Land of 5 Towers.

\section{Introduction}

Language is very important for all people in the world, it is used to communicate, to get information, to share information, to express idea even to control the society. In its implementation, there are many languages. It caused as the cultural differences that make people may use more than one language, which is cannot be understand by all people. In this case translation activity takes an important role, to understand the communication.

Translation activity is an art. It has been noted by some expert. Not only as an art, but also regarded as a science and a skill, which need the ability of the translator to convey the idea well. For that reason, there are 
some techniques of translation that can be used in order to get good translation. Translation techniques used by a translator in translating a work is very interesting to analyze to find out whether the source language is equivalent into the target language.

The main point of translation activity is the message in both source language and target language in the text of the works. In carrying out translation activity, translators often encounter difficulties due to differences between the source language and the target language. Therefore, it is necessary to use the right techniques so that the message in the source language can be delivered well in the target language.

Besides, translation works can help readers not only to understand the meaning of foreign language but also increase the understanding of cultural differences. In other words, translation works can help people to solve the problem which can be caused by the cross-cultural two-language communication among people.
Since translation techniques contribute a lot to convey the parallel meaning to the translated text, thus, talking about translation techniques is interesting. The writer chooses to analyze translation because translation is one of the important subjects to study. Related to the idea, the writer is interested in analyzing a translation work, an Indonesian novel, Ahmad Fuadi's Negeri 5 Menara which is translated into Angie Kilbane's The Land of 5 Towers by focusing on translation techniques used in the work.

Translations techniques are interesting aspects to analyze because they will show how the idea in source language is conveyed in the target language. Besides it will also show how cultural elements can be presented in such a way and in the same time it still keeps the idea.

Parallel to the idea above, this analysis will focus on analyzing the translation techniques used in translating an Indonesian novel, Ahmad Fuadi's Negeri 5 Menara into 
Jurnal Ilmu Budaya, Vol. 18, No. 1 Agustus Tahun 2021

Angie Kilbane's The Land of 5

Towers.

The objectives of the research are:

1. to analyze the translation techniques used in translating Ahmad Fuadi's Negeri 5 Menara into Angie Kilbane's The Land of 5 Towers.

2. to describe the most dominant translation techniques used in translating Ahmad Fuadi's Negeri 5 Menara into Angie Kilbane's The Land of 5 Towers.

\section{Theoretical Framework}

\section{A. The Concepts Of Translation}

There are many experts who define translation. Translation is understood as reproducing the target language with the nearest similarity of the source language. This target language should be find the equivalence in the source language, it is urged by Nida and Taber in El-shafey (1982: 12) who state, "Translation as a process of reproducing in the receptor language the closest natural equivalent of the source language message, first in terms of meaning and secondly in terms of style".

Other than that Wilss in Elshafey noted (1982: 3) "Translation is a transfer process which aims at the transformation of a written source language text (SLT) into an optimally equivalent target language text (TLT), and which requires the syntactic, the semantic and the pragmatic understanding and analytical processing of the source text".

Moreover, it has been argued by Newmark in El-shafey (1981: 7) "Translation is a craft consisting in the attempt to replace a written message and/or statement in one language by the same message and/or statement in another language". In Newmark's view (1991: 27) he defines, the act of translating very briefly. It is the act of transferring meaning of a stretch or a unit of language, the 
whole or a part, from one language from another.

Furthermore, Brislin (1976: 1) describes "Translation is a general term referring to the transfer of thoughts and ideas from one language (source) to another (target), whether the languages are in written or oral form; whether the languages have established orthographies or do not have such standardization or whether one or both languages is based on signs, as with signs of the deaf'.

Withal, Krishna Regmi (2010: 17) states "Translation as a process where the meaning and expression in one language (source) is tuned with meaning with another (target) whether the medium is spoken, written, or signed". Krishna Regmi (2010: 18) also states that "Translation as a process of converting ideas expressed from one language into another, was embedded the translation process as basically a boundary-crossing between two different language."
Withal, Krishna Regmi (2010: 17) states "Translation as a process where the meaning and expression in one language (source) is tuned with meaning with another (target) whether the medium is spoken, written, or signed". Krishna Regmi (2010: 18) also states that "Translation as a process of converting ideas expressed from one language into another, was embedded the translation process as basically a boundary-crossing between two different language."

According to Shadeghi

"A good translate on is easily understood, fluent, and smooth, idiomatic. Translation coveys to some extent, the literary subtitles of the original, distinguished between the metaphorical and the literal, reconstructs the cultural or historical context of the original. A good translation makes explicates what is implicit in abbreviations, and an illusions to saying, songs and nursery rhymes, for last criteria that good translations will convey as much as possible the meaning of the original text" (Shadeghi 2010:3). 
From the definitions above, it can be cited hat translation is defined as transferring meaning from one language (source) to another language (target). For instance; Indonesia into English or English into Indonesia. The translators should be careful when translating the works, so it's not misunderstood.

\section{B. The Process Of Translation}

There are some processes in translating works. Some experts classifiies it into many kinds of processes based on their understanding. According to Larson (1984: 15) translation is classified into two types, named form-based translation and meaning-based translation. Form-based translation attempts to follow the form of the source language (SL) and it is known as literal translation, while meaning based of the SL text in the natural forms of the receptor language. Such translation is called idiomatic translation.
In Larson's view also a literal translation sounds like nonsense and has little communication value (Larson: 1984: 15). The literal can be understood if the general grammatical form of the two languagees is similar. Larson (1984: 16) says that idiomatic translation uses the natural form of the receptor language both in grammatical construction and the choices of lexical items. A truly idiomatic translation does not sound like translation. It sounds like it was written originally in the receptor language.

Besides, Newmark (1988: 122) classified translation into three basic elements. The process are:

The interpretation and analysis of source language text. The translation procedures, which may be direct, or based on SL and TL corresponding syntactic structure.

The reformulation of the text in relation the writer's 
attention, the reader's expectation, the appropriate norms of TL and so forth.

Furthermore Larson (1991: 1) adds more items to get an ideal translation. First, translation should be accurate, it means the text produce should exactly have the same meaning with the source language. Secondly, it should be natural, translation using natural forms of the target language in a way what is readily understandable to the intended audience. Third, it should be communicative, expressing all aspects of the meaning in a way that is readily understandable to the intended audience.

Larson (1998: 3) applied the translation process as in diagram below:

\section{OVERVIEW OF THE TRANSLATION TASK}

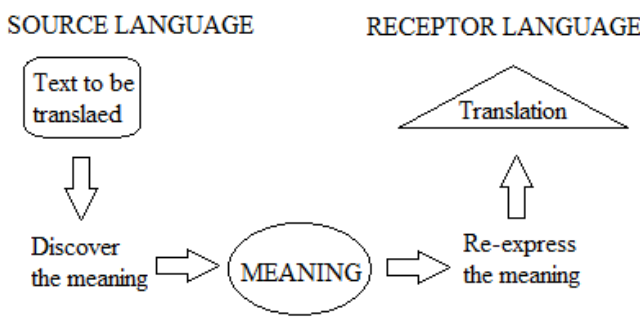

The diagram above shows the process of translation, it can be found that there are three major steps in the process of translation. First, a translator needs to discover the meaning of the message in the source language (there is a text to be translated). After the translator gets the meaning, the process of determining the meaning that related to the communicated is needed. Finally, a translator needs to re-explain or re-express the meaning (the message) in target language using the translation equivalent.

\section{The Principle of Translation}

$$
\text { Duff (1989: }
$$
announces the principle of translation as follows:

1. The translation should reflect accurately the meaning of the original text.

2. The order of the words and idea in the translations should match 
the original idea as closely as possible.

3. Languages often differ greatly in their level of formality in a specific context.

4. Many translations do not sound natural.

5. The translator should not change the style of the original as much as possible.

6. Idiomatic expression is an expression whose meaning cannot be inferred from meanings of words that make it up.

Moreover, Tytler in Bell (1991: 11) states that there are some principles of translation namely:

1. The translation should give a complete transcript of the ideas of the original work.

2. The style and the manner of writing should be of the same character with that of the original.

3. The translation should have all the ease of the original composition.
So, the importance of translation is the transferring message from source language to target language, without changing the idea.

\section{Translation Techniques By Molina And Albir}

Translation techniques as procedures are used to analyze and classify how translation equivalence work. It means to transfer message from source language to the target language, it applies at the level of words, phrases, clauses, or sentences.

$$
\begin{aligned}
& \text { There are eighteen } \\
& \text { techniques of translation } \\
& \text { introduced by Molina and Albir } \\
& \text { (2002), they are: }
\end{aligned}
$$

1. Borrowing is classified into two kinds; Pure Borrowing and Naturalized Borrowing. It is supported by the study conducted by Molina and Albir (2002: 509511), "To take a word or expression straight from another language. It can be pure (without 
Jurnal Ilmu Budaya, Vol. 18, No. 1 Agustus Tahun 2021

any change) or it can be

naturalized (to fit the spelling rules in the TL)".

1.1 Pure Borrowing means translating a pure text or without any change from source language into target language. It only takes one word. The example: Santri Santri

\subsection{Naturalized Borrowing means} to fit the spelling rules in the target language. The same wih pure borrowing, it takes one word. The example: Endemik Endemic

2. Calque is words of phrase that borrowed from another language by literal or word-by-word translation or origin words. It is supported by the study conducted by Molina and Albir (2002: 509511) who state that, "Calque is literal translation of a foreign word or phrase; it can be lexical or structural". The example: Telaga Bodas - White Lake
3. Literal Translation, not only finds the word or phrase that is equivalent with the target language, but also adjusts arrangement or appropriate grammatical and close to source language. It is commonly found in the short sentences. This is urged by Molina and Albir (2002: 509511) who states that, "To translate a word or an expression word for word. The example: Kami bukan malaikat atau burung perkutut. We are not angels or turtledoves.

4. Compensation, according to Molina and Albir (2002: 509-511), is "To introduce a ST element of information or stylistic effect in another place in the TT because it cannot be reflected in the same place as in the ST". The example: Bung! - Friend!

5. Transposition, involves moving from one grammatical category to another without altering the meaning of the text. This technique introduces a change in grammatical structure. This is urged by Molina 
Jurnal Ilmu Budaya, Vol. 18, No. 1 Agustus Tahun 2021

and Albir (2002: 509-511), "To change a grammatical category". The example: Anak yang nakal - A naughty child".

6. Description, provides a description or explanation of the source language in order to be understood in the target language. This is urged by Molina and Albir (2002: 509-511), “To replace a term or expression with a description of its form or/and function". The example: Pak Harfan menatapnya kosong. - Pak Harfan stared at her with an empty look in his eyes.

7. Modulation, is about changing the form of the text by introducing a semantic change or perspective. This is urged by Molina and Albir (2002: 509-511), "To change the point of view, focus or cognitive category in relation to the ST; it can be lexical or structural". The example: Mencari seorang teman hidup - To take a wife.

8. Amplification, explains the detail. This is urged by Molina and Albir
(2002: 509-511), “To introduce details that are not formulated in the ST: information, explicative paraphrasing". The example: Lyre yang menjadi milik Orpheus - the Lyre music instrument like harp that belonged to Orpheus.

9. Adaptation, replaces the original text with one that is better to the culture of the target language (cultural equivalent). This is supported by Molina and Albir (2002: 509-511) who state that, "To replace a ST cultural element with one from the target culture". The example: Kotak P3K - First aid kit.

10. Establish Equivalent, expresses something in a completely different way, for example when translating idioms to slogan. This is also supported by Molina and Albir (2002: 509-511) who state that, "To use a term or expression recognized (by dictionaries or language in use) as an equivalent in the TL. The example: Bagaikan 
pinang dibelah dua - They are as like as two peas.

11. Generalization, uses more general term at the target language, for source language more specific because target language doesn't have any specific equivalent. This is urged by Molina and Albir (2002: 509-511), “To use a more general or neutral term". It is in opposition to particularization. The example: Mendelik-delik seperti mata ikan gurami - Glared like an engaged fish.

12. Particularization, is a translation procedure in which the translator uses the term more concrete or specific, from superordinate to subordinate. This is also urged by Molina and Albir (2002: 509-511), "To use a more precise or concrete term". It is in opposition to generalization. The example: Pesta - Wedding Party.

13. Reduction, is a technique that implicit information on the source language be implied other words do not occur disappearances message. This is supported by Molina and Albir (2002: 509-511) who state that, "To suppress a ST information item in the TT". The example: Terasa sekali betapa besarnya perubahanku dibanding dengan dulu - I realized how much I had changed.

14. Discursive Creation, is used to translate the title of the book or movie and sometimes is always out of the context. This is also supported by Molina and Albir (2002: 509-511) who state that, "To establish a temporary equivalence that is totally unpredictable out of context". The other example: Labirin Kenangan Rememberance.

15. Substitution, changes the meaning of paralinguistic expression. This is urged by Molina and Albir (2002: 509-511), “To change linguistic elements for paralinguistic elements (intonation, gestures) or vice versa". The example: Dia setuju - (She is nodding). 


\section{Linguistic}

Compression, compresses the elements in the receptor language. This is also urged by Molina and Albir (2002: 509-511), "To synthesize linguistic elements in the TT. This is often used in simultaneous interpreting and in sub-titling". It is in opposition to linguistic amplification. The example: "Kemarin sore" - "Yesterday".

17. Linguistic Amplification, is usually about using a paraphrase to explain a word that has no equivalent in the target language. This is supported by Molina and Albir (2002: 509-511) who states that, "To add linguistic elements. This is often used in consecutive interpreting and dubbing". It is in opposition to linguistic compression. The example: "Siapa?" - "Who are you?".

18. Variation, is a technique used by replacing elements of linguistic or paralinguistic that have an impact on linguistic variation. This is also supported by Molina and Albir
(2002: 509-511) who state that, "To change linguistic or paralinguistic elements (intonation, gestures) that affect aspects of linguistic variation: changes of textual tone, style, social dialect, geographical dialect, etc., e.g., to introduce or change dialectal indicators for characters when translating for the theater, changes in tone when adapting novels for children, etc". The example: "Sampai jumpa" - "See yea".

\section{Research Methodology}

This research is to find the translation techniques in the novel. In doing this research, the writer uses library research. According to Nazir (1998: 111), library research is to conduct a study review of books, literature, records, and reports that had to do with the problem solving.

Leedy argues that the aim or the purpose of the research library is to reveal similar studies with research that (will) we help give an idea of the methods and techniques used in the 
study who had similar problems to the research we face.

This analysis analyzes the translation techniques in translating Ahmad Fuadi's Negeri 5 Menara Into Angie Kilbane's The Land of 5 Towers. Thus, the source data of this analyze are those two novels, particularly the data dealing with the translation techniques.

This research will explain the techniques used in translating Ahmad Fuadi's Negeri 5 Menara Into Angie Kilbane's The Land of 5 Towers. Moreover, this research will describe the most dominant techniques used. In this research, the writer applies a descriptive method. In Whitney's view, descriptive method is fact-finding with interpretation. It means that the writer need to collect facts and all relevant information.

There some are steps to apply in descriptive method. Firstly, the witter need to identify a phenomenon. Then, consider the caracteristics of the phenomenon are most dominant. Next, identify the constructs (measures) that best represent the caracteristics. After this, determine whether there are observable patterns in the data. Next, communicate the patterns in the data that describe the realities of the phenomenon. Finally, rethink and repeat as needed.

\section{Findings}

\section{Translation Techniques}

\section{a. Pure Borrowing}

The first data "Bagai mengenakan kopiah haji" in Indonesian is translated into "As if wearing a kopiah cap for the Hajj" in English. Kopiah means the kinds of cap worn by muslim men and also by Indonesian men as a symbol of national identity. The word kopiah doesn't have any change.

The second data in Indonesian sentence "Tiga tahun aku ikuti perintah Amak" is translated into English "For three years I'd followed the orders of my Amak". Amak is a word for mother in most Minang areas. The 
word amak doesn't have any change in English either.

The third data "Kacang tojin" which is translated into English "Tojin peanuts". Onion peanuts known as tojin peanuts in Padang, Indonesia. It is common snack that especially during Eid and other celebration days. The word tojin doesn't have any change in English either.

Pure Borrowing is used because kopiah, amak, and tojin are Indonesian words which are not found in English, there are no equivalent.

\section{b. Naturalized Borrowing}

First, "Kursi rotan tempat dudukku..." is translated into English "The rattan chair I was sitting...". Rotan is a palm tree tribe in the Calamoideae subfamily. In Indonesia, rotan changed by crafts maker into furniture as chairs, cradles, tables, etc. The word rotan becomes rattan, to follow the nature of English spelling.

Second, "Berwarna marun dengan kelim-kelim keemasan" is translated into "Maroon with gold stiching". Marun is kind of dark red color. The word marun is changed into "maroon". It is changed because the spelling follows the nature of the English sounds /u/ into /u:/ (long).

Third, "Warung sate paling enak" is translated into "The most delicious satay restaurant". Sate is food made from small pieces of seasoned meat, skewered and grilled, then served with a souce. The same as maroon, It is changed because the spelling of Indonesian follow the nature of English sounds /e/ into /ai/.

\section{c. Calque}

First, Indonesian phrase "Baju kurung hijau" is translated into English "Green baju kurung". The phrase baju kurung is not 
changed because baju kurung is not found in English.

Next, in Indonesian phrase "Kelok Ampek Puluah Ampek" in English is translated into "Kelok Ampek Puluah Ampek”. Kelok Ampek Puluah Ampek is one of long notorious road located in West Sumatra. Kelok Ampek Puluah Ampek also has Indonesian sense.

Then, "Film layar tancap" this phrase is translated into "Layar tancap film" in English. In Indonesia, film layar tancap is the outdoor film show with a screen and a pole plugged into the ground. The same as the data no. 1 and 2 it also has Indonesian sense.

\section{d. Literal Translation}

The first data in Indonesian sentence "Aku tersenyum.

Pikiranku langsung terbang jauh ke masa lalu. Masa yang sangat kuat terpatri dalam hatiku" is translated into "I smiled. My thoughts immediately flew far away to the past. Every strong period eteched in my heart". All of the words are translated word by word and follow the grammatical rules of English.

The second data in Indonesian sentence "Daging, ikan, susu, buah menjadi kejutan yang menyenangkan dan berguna untuk menyiapkan stamina kami menghadapi ujian" for English "Meat, fish, milk, and fruit became pleasant and useful surprises for preparing our stamina to face exams". It is translated word for word and follows grammatical rules from Indonesian into English.

The third data in Indonesian sentence "Aku tidak tahu apa yang membuat perlawananku runtuh dengan mudah" which is translated into "I didn't know what made my resistance collapse so easily". It is translated literaly and fits the English grammatical rules.

\section{e. Compensation}

First, "Nak, ada surat dari Pak Etek Gindo," is translated into "Son, there's a letter from Uncle 
Gindo," The underlined Indonesian word cannot reflect the same meaning in English.

Second, translated from Indonesian "Aku baca surat $\underline{\text { Pak }}$ Etek Gindo" into English "I read Uncle Gindo's letter". In Indonesia, exactly in Minangkabau Pak Etek is an address for young brother or sister of mother or father, which cannot fit the same meaning in English.

Third, "Bang, ambo ingin berlaku adil" is translated into English "Dear, I want to be fair". Bang in Indonesian is an intimate address for husband. It cannot be applied into English because it has different meaning and sense.

\section{f. Transposition}

The first data, "Dengan $\underline{\text { muka rusuh" to be "With a trouble }}$ face". It is translateable because the change position of the word from Indonesian into the English is different and it follows English grammatical structure.
The second data, "Surga di bawah telapak kaki ibu" is translated into "Heaven is under the mother's heel.". Apostrophe's is possessive pronoun form according to English grammatical rules.

The third data, "Sebuah buku berjudul Biografi Kiai-Kiai Pendidik" into English "A book titled Biographies of Kiais in Education". In Indonesian underlined word become biographies follows English grammatical category, singular is changed into plural form.

\section{g. Description}

The first data in Indonesian sentence "Kegiatan kami setiap hari dimulai jam 4" the translator adds the information in English "Our activities every day start at 4:00 in the morning". The translator adds the information in English to explain at 4:00.

The second data in Indonesian sentence "Belum pernah menonton film di bioskop selain 
film G-30 S PKI" is in English "I'd never seen any movie at theater other than the G-30S PKI movie about the communist uprising". The additional information in English is to describe the G-30S PKI movie. It makes the readers understand.

The third data in Indonesian sentence "Untung ada Said yang rajin mentraktir kami” into "Luckily there was Said who diligently treated us to snack". The translator adds the information in English to explain "treated".

\section{h. Modulation}

In translating from Indonesian into English "Semua lengkap" to be "All done" is changing perspective.

Next, translating from Indonesian "Berdinding bata merah yang dibiarkan polos terbuka tanpa

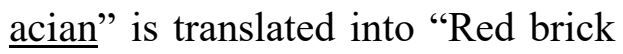
walls that were intentionally not painted". The underline phrase in Indonesian is translated into different point of view in English.
The words are different but they have the same idea.

Then, "Memakainya sebagai

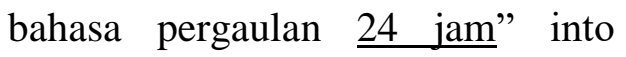
English "Use them as our conversational language all the

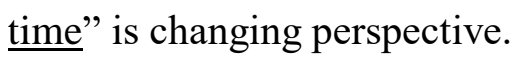

\section{i. Amplification}

First data "Di akhir rakaat" becomes "In the last raka'ah or prayer movement". Raka'ah consist of the prescribed movements of sholat (once stand, once ruku, sujud twice). The detail information is put in English.

Second data "Giliran dia bercerita tentang karapan sapi" is translated into "During his turn, he told about karapan sapi, the famous bull races in Madura". The detail is also informed in English.

Third data "Kami baru kembali masuk sekolah pertengahan bulan Syawal" is translated into "We'd come back to school again in the middle of the Shawwal month of the Islamic calendar". The 
translator adds more information in English.

\section{j. Adaptation}

In Indonesian sentence "Washington DC, Desember 2003, jam 16.00" becomes "Washington DC, Desember 2003, 4:00 pm". The appointment time is only up to 12 and the author or Indonesian culture using 24 hours form for day and night, while the translator using English which differentiates 2 periods, 12 noon and 12 at night. Am. to indicate periode of time start from 00:01 - 11:59 (midnight to noon) and Pm. indicates periode of time start from 12:00 - 23:59 (noon to midnight)

"Belajar di madrasah tsanawiyah" refers to Indonesian formal education in Indonesia which is specific school studying more Islamic doctrines. It has same levels as junior high school. This school is managed by Ministry of Religion Indonesia. The translator translate into English as "Study at an Islamic junior high school”.

In translating "Inilah Malam Syukuran Ujian Akhir" becomes "This was the Final Examination Thanksgiving Night". In Indonesian "Syukuran" is a pray and eat together ceremony. It is held not only at night but also at noon. It is translated into English "Thanksgiving" by translator which refers to a day of thanking to God for the blessing of the harvest and of the preceding year. "Thanksgiving" is the analogy of "Syukuran".

\section{k. Established Equivalent}

In Indonesian phrase "Jauh panggang daripada api" it means it is not as expected, translate into English "Easier said than done" which means easy to say but hard to do.

To Translate "Tangannya menetak pergelangan tangan $\underline{\text { si }}$ hitam" is an Indonesian idiomatic expression, into "His hand grabbed 
the robbers arms". Si hitam in the that text refers to thief.

Indonesian phrase "Kami bertiga, aku, Dul dan Said menjad buah bibir dan terkenal" translated into English "The three of us-Dul, Said, and me - became the famous topics of conversations". The phrase buah bibir may not be translated into literaly, for it will cause misunderstanding.

\section{Generalization}

First data, "Terparkir rapi tujuh sepeda ontel" translate into "Seven bicycles were neatly parked". The underlined phrase sepeda ontel is a type of bicycles which is used by the people at that time. Then, this phrase sepeda ontel made more common into bicycles into English.

Next, Indonesian sentence "Berempati kepada para penghuni taman safari yang asli" is translated into "Give our empathy to the real zoo residents". The phrase taman safari is the a Finding al theme parks located in Bogor. In English version into zoo, translate more general by translator.

Then, to translate Indonesian "Walau begitu, badan setelan melayuku tetap menggigil melawan suhu yang anjlok" translated into "Even so, my Indonesian body still shivered, battling the temperature, which had plummeted". Melayu is one of Indonesian ethnic groups. It is translated by translator into English as Indonesian which is more general.

\section{m. Particularization}

The underlined phrase in Indonesian sentence "Tempat tujuan wisata terkenal di ibukota Amerika Serikat" translated more specific into "Famous tourist attraction in Washington". Amerika Serikat is the country located in the central part of North America, while Washington is the capital city of America. 
Jurnal Ilmu Budaya, Vol. 18, No. 1 Agustus Tahun 2021

To translate "Puncaknya
yang tiang untuk menumpangkan
corong TOA" becomes "Its high
peak had huge speakers". TOA is
actually Japanese electronics
company, specializing in public
address systems, intercom systems,
microphones, etc. However, the
translator translates it by using
more particular term into speakers.
Then, "Aku coba pandang
mukanya" translated into "I tried to
look him in the eye". In Indonesian
sentence use muka which means
face, but in English translated into
eye which means mata. Whereas
eye is a part of face then translator
translate into more specific, muka
into eye.

\section{n. Reduction}

In Indonesian "Kepalanya

selalu ditutup songkok dan dilehernya tergantung selendang." translated into "Her head was always covered with a colorful scarf" into English. It suppresses the information item from

Indonesian.

Then, "Ayahnya atau kakekku yang aku panggil Buya Sutan Mansur adalah orang alim yang berguru langsung kepada Inyiak Canduang atau Syekh Sulaiman Ar-Rasuly." translated into "Her father, my grandfather, who I call Buya Sutan Mansur, was a pious man and a student of Syekh Sulaiman Ar-Rasuly".

In translating the Indonesian sentence "Permintaan doa buat keluarga PM yang sakit mulai dari Sorong sampai Aceh, hingga doa buat alumni yang meninggal" translator cuts some words in English "Requests for prayers for sick MP family members and prayers for alumni who'd passed away".

\section{o. Discursive Creation}

The first is the title of the novel itself "Negeri 5 Menara" which is translated into "The Land 
of Five Towers". It is the creation of the translator.

The second is the sub-title of the novel "Bung Karno" is translated into "Sukarno". The word "Bung" in Indonesian is close address for a man.

\section{p. Substitution}

"Sambil menunduk aku paksakan bicara." is translated into English "Lowering my head, I was forced to speak". It translates the phrase to be paralinguistic; gestures.

Translator translates

paralinguistic to be phrase. "Setelah mendehem, dia memperkenalkan diri" as "After clearing his throat, he introduces himself".

"Tidak ada yang berani berleha-leha" means enjoy and relaxed the feel without doing anything translate into English "No one dared drag his feet" to be action. Translator translate phrase into paralinguistic; gestures.

\section{q. Linguistic Compression}

To translate "Betul, ini siapa, ya?" into "Yes, who is this?" it doesn't change the idea totally.

The Indonesian "Cak kau lihat ini bos," is translated into English "Look at this," it cuts some linguistic elements in Indonesian.

Then "Ambil posisi berbaris bersaf" from Indonesian into English "Line up!" unifies linguistic elements in English.

\section{r. Linguistic Amplification}

The translation of Indonesian "menara keempat, ingat gak?" into English “manara four, do you remember or not?" In English, translator puts some linguistic elements.

It can also be seen in Indonesian, "Tahu kesalahan kalian?" becomes "Do you know what you've done wrong?" Linguistic elements are added by translator in English which not exist in Indonesian. 
Jurnal Ilmu Budaya, Vol. 18, No. 1 Agustus Tahun 2021

To translate Indonesian

"Tentu saja," to be "Of course I have," in English, the translator adds more information in English.

\section{s. Variation}

First, "Teng... teng... teng... teng... Suara lonceng besar" is Indonesian textual tone translated into English as "Ding...ding...ding...ding... The sound of the big bell".

Next, "Prit...prit...prit... begitu irama peluit" also Indonesian textual tone translated into English becomes "Tweet...tweet...tweet... whistles blew".

Then, "Hajar... hajar... hajar..." in Indonesian it is changed into “Get em'! Get em'! Get em'!". The changes occurs because of variety of informal and nonstandard language.

\section{CONCLUSIONS}

This analysis deals with The Analysis of Translation Techniques in Translating Ahmad Fuadi's Negeri 5
Menara into Angie Kilbane's The Land of 5 Towers. This analysis is a library research and applying descriptive method. From the analysis, the writer found that the translator applies all of eighteen techniques translation by Molina and Albir. They are sort by high data as following: Modulation with 69 data. Adaptation with 33 data.Transposition with 27 data.

Pure Borrowing with 23 data. Reduction with 22 data. Amplification with 18 data. Naturalized Borrowing, Literal Translation and Generalization with 17 data. Calque with 13 data. Description with 9 data. Variation with 7 data. Established Equivalent with 6 data. Substitution, Linguistic Compression, and Linguistic Amplification with 5 data. Compensation and Particularization with 4 data. Discursive Creation with 2 data.

From the eighteen techniques used it is found out the most dominant technique used by translator is Modulation. It is because translator use 
more familiar diction in order to makes the readers easy to understand in English. Then, the most less technique used is Discursive Creation. It is because the translator cannot found the equivalency that is totally unpreditable out of the context from Indonesian into English.

\section{SUGGESTION}

\section{Analyzing}

translation

techniques is interesting for the writer. In this research the writer only analyzes the translation techniques used and the dominant techniques used. The writer realizes that this thesis is giving limited information. There are much more to be discussed. This thesis provides some information about translation techniques. It is expected that give beneficial and helpful for the next researcher who are also interested to analyzing translation techniques.

\section{BIBLIOGRAPHY}

Bell, R. T. 1993. Translation and
Translating: Theory and
Practice. London: Longham. 2Ed.

Brislin, R. W. 1976. Translation: Application and Research. New York: Garden Press, Inc

Descriptive analysis in education: A guide for researchers. 2017.

Accessed on January 14, 2019, at 9 a.m, from https://files.eric.ed.gov/fulltext /ED573325.pdf

Duff, A. 1989. Translation. London: Oxford University Press.

El-shafey, Fatma. 2012. Simultaneous Translation. Accessed on January 14, 2019, at 9 a.m, from

http://olc.bu.edu.eg/olc/images/ fart/425.pdf

Larson, M. L. 1984. Meaning-Based Translation: A Guide to Cross Language Equivalence. Lanham Md: University Press of America, Inc.

Leedy, P. D. 1997. Practical Research: Planning and Design. New Jersey: Prentice Hall. Upper Saddle River

Molina, Lucia, and Amparo Albir. 2002. Translation Techniques Revisited: A Dynamic and Functionalist Approach. Meta, XLVII, 4. 498-512 
Jurnal Ilmu Budaya, Vol. 18, No. 1 Agustus Tahun 2021

Nazir, Mohammad. 1998. Metode Penelitian. Jakarta: Graha Indonesia

Newmark, P. 1988. A Textbook of Translation. New York and London: Prentice Hall

Regmi, Krishna. 2010. Understanding the Process of Translation and Transliteration I Qualitative Research. International Journal of Qualitative Methods. Pp 16- 26

Shagedhi, G. A. 2010. All New Theories and Concept about Translation in New Century. Pp 1-15

The Descriptive Method in Social Research. Indian Sociological Society. Accessed on January 14, 2019, at 9 a.m, from https://www.jstor.org/stable/4 2864589

Translation Theory and Practice.Accessed on January 14, 2019, at 9 a.m, from http://www.seasite.niu.edu/tran s/articles/Translation\%20Theor y\%20and\%20Practice.htm 